\title{
DYNAMICS OF LOCAL ISLAM: Fatwa of Muhammad Basiuni Imran, the Grand Imam of Sambas, on the Friday Prayer Attended by Fewer than Forty People
}

\author{
Hamka Siregar \\ Pontianak Institute of Islamic Studies
}

\begin{abstract}
This article is an analitical work based on local Islam dynamic of Sambas society in the era of Sambas Sultanate. The work attempts to promote intellectual heritages such as the book of Cahaya Suluh, which could at least give us an idea that in a process of setting certain rules or istinbat, there is a need for flexibility. As can be observed from the whole argument built in this book, the process is completely flexible, not merely following one school of thought. As indicated in this paper, especially in the discussion of his thought, Muhammad Basiuni Imran used various references for his propositions. Although he was an advocate of the school of Syaf'i, he was still open to the other schools of thought. As a matter of fact, in the case of Friday prayer, his position was different from the school of thought he supported. He took that position because he considered the socio cultural conditions of Sambas at the time. Intellectual spirit shown by the Grand Imam of Sambas should continue to be emulated and expanded. It is a way to avoid the 'blind' taqlid against a certain school of thought, as such attitude can narrow human intelligence and reasoning which will eventually lead to collision with local reality that sometimes contains values that do not contradict with religion. In addition, the approach to the interpretation of law should look at its socio-cultural and historical background as this will keep the law strong and sustainable. In this way, Islam will be easily accepted without having to impose foreign culture on local people.
\end{abstract}

Keywords: Dynamic, Islam, Sambas, Grand Imam, Muhammad Basuni Imran

\section{INTRODUCTION}

Islam is, in fact, not a native religion of Indonesia. Long before the arrival of Islam, other religions, such as Hinduism and Buddhism, were already embraced by most of the inhabitants of the Archipelago. Traces of the two religions can still be seen in many parts of the country. By the will of God, within quite a long time, things changed. Islam then took the position of the two religions. The spread of Islam significantly occurred in the 12th century and the process of Islamization appears to have accelerated between the 12th and $16^{\text {th }}$ century (Muhsin, 2007: 6). During this long period, the Islamic 
religion had been "naturalized" with the natural taste of the Archipelago so that it experienced a variety of adaptations. As it arrived at different natural conditions, different social construct, and different psychological, Islam should be ready for adjustment. This "guest" religion had to cleverly communicate itself into the local community that had its own belief system. Therefore, it is not uncommon when religion is presented to the public sphere, it must be packed in such a way in order to respond to and accommodate local values and interests, without having to remove the substance or the essence of the teachings of the religion itself.

The first wave of the transmission of Islam to Indonesia according to historians was done through Sufis who came for religious proselytization and commercial interests. This Sufic pattern made the entrance to spread Islam in the society (Mu'jizah; 2005: VII). With this Sufic approach, it seems that the Sufis have a place in the hearts of local residents. The Sufic religious nuances are still strong in Indonesia's Muslim community, particularly among those who maintain traditional religious values such as the tariqa groups (tariqah Naqasabandiyah, Satariyah, Khulwatiayah etc.). Although not very open, these groups still exist and have a lot of followers.

The momentum accelerated the spread and absorption of the religious messages considerably. More importantly, with this pattern, the dissemination and absorption of this new religion in society did not experience a clash of values. It can be said, as reviewed by Azhar Arsyad - Rector of the UIN Makassar---Islamization process Archipelago run in cool and peaceful (in Komarudin Hidayat; 2006: 73). A person could become a Muslim without losing his/her distinct identity. It can be seen how Islam is negotiating with local culture of Javanese, Sundanese, Malay, Batak and land Parmalim, etc. Although culturally retaining their traditions, but they have enriched the values of Islam with their distinct local exquisiteness.

Further development shows that the definition of the Islamic tasamuh (tolerance) that gives space to and considers the local values is changing. In recent years, there have been movements to bring purification of Islam to its authentic form in the midst of the community. They intend to revive Islam to its original version of its birthplace (Mecca). They view the current Islamic teachings have been mixed with traditional values, and these local values have corrupted the purity of Islam. Therefore, certain groups immediately want to clean it up so that the sanctity of religion will not be contaminated with heresy, superstition and idolatry. Authentic Islam, so they expect, should replace the Islam that has been mixed with local traditions. The process of purification and authentication that can be referred to as "radical salafi" project has triggered 
tensions between religion and local traditions. In the end, the obsessive purification will hurt the harmony between Islam with the local culture. Since then, the tension could no longer be properly mediated.

In fact, religion and culture are inseparable; there is no distance between them. Even though religion is not a human product, when it is understood by humans, then it will experience the process of humanity known as "contextualization". This is a process of understanding the contextualization of religion empirically or religion that appears in its formal form in the community (Abudinata; 2002: 49). Religious experience is processed by the believer through reasoning from the source of religion, i.e. revelation. When reading the book of fiqh, for example, one should see it as derivation of the Qur'an and the Hadith. Therefore, the fiqh practiced by certain groups in a community is the result of reasoning known as ijtihad. Thus, religion can be said to be the product of God as well as humans. Religion that appears in its form is related to the culture that developed in the community where the religion flourished. Therefore, through a correct understanding of culture, one will be able to apply their religious teachings without conflict.

Erich Fromm in Nourouzzaman Shiddiqi (1996: 258) argued that there is no culture which is not rooted in religion. Interconnection between religion and culture thus creates civilization as illustrated in following diagram:

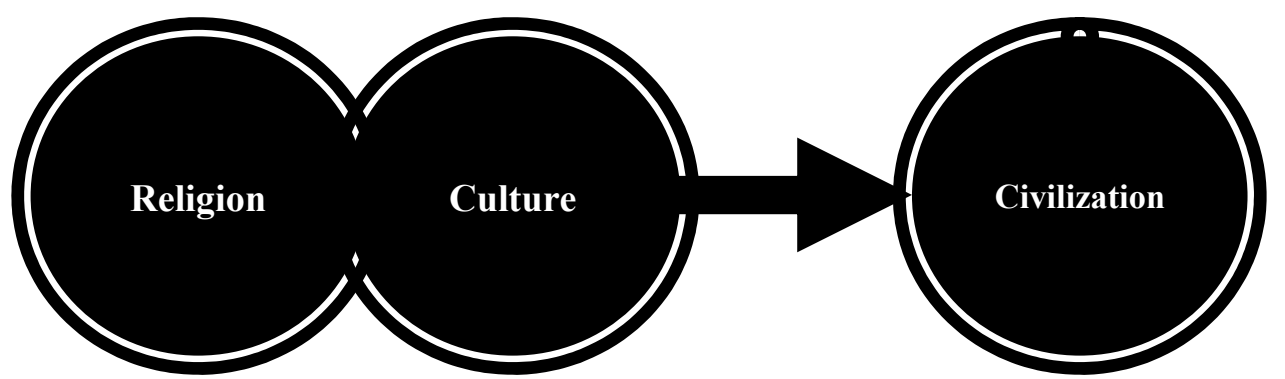

The relationship between religion and culture, especially in Indonesia, can be seen in research conducted by Geertz (1956) in a small town in Central Java, Mojokuto. He found out that Islam has become an ideal culture in Indonesian society, especially in rural areas. The discovery of Geertz's observations was supported by Van der Kroef (1959), a Dutch historian. Geertz and Kroef's observation was reinforced by S Soebardi and Woodcraft-Lee (1982) who argued that any attempt to understand the character of the present Indonesian community and its cultural heritage cannot be separated from the study of the role of Islam, both as a religion and as a social and political force. Therefore, the relationship between religion and culture has become Indonesia's cultural character. (Nourouzzaman Shiddiqi; 1996: 258) 
Thus the truth of Islam is expressed in a variety of colors and forms, in line with the inevitability of different languages, cultures and customs and adherents. To that end, all religious expression within a cultural frame should be seen as a religious expression and can hardly be separated by cultural aspects. Religion and culture go hand in hand because religion teaches the truth and culture accommodates positive things that do not reject anything that is not contrary to the local wisdom. Local wisdom will provide space with the reality of various faces of Islam. When Islam encounters variants of local culture, then it progresses to a process of enriching each other. Thus, the emergence of various variants of Islam in Indonesia, such as Javanese Islam, Madurese Islam, Malay Islam, Sasak Islam, and so on, each of which features the distinct characters from each other.

The attachment between religious values with local culture can be seen in the intellectual works of the scholars who used local languages, such as Javanese, Bugis, Sundanese, Madurese and Malay. Nihayatuz Zein, for example, is a book written in Javanese by Sheik Nawawi al-Bantani a scholar from Banten. Cahaya Suluh by Muhammad Basiuni Imran- the subject of discussion in this paper-was written in Arabic-Malay. They, the scholars of the past, in general wrote religious books which served as reference for their students and other Muslims when they left for other areas or died (Erwin et al., 100: 2003).

Azra Azumardi (1995: 243) stated that in the 18th century until the early 19th century there were several leading scholars of Malay Indonesian from different regions and ethnic groups, such as those from Sumatra, Java, Kalimantan and Sulawesi. The most important among them was Syihab al-Din bin Abd. Allah Muhammad, Kemas Fakhr al-Din, Abd al-Shamad al-Palimbani, Kemas Muhammad bin Ahmad and Muhammad Muhyi al-Din bin Syihab al-Din. Furthermore, Muhammad ArsyadAl-Banjari from South Kalimantan, Abdul Wahhab al-Bugisi from Sulawesi, Abd al-Rahman al-Mashri al-Batawi of Batavia (Jakarta), and Daud bin Abdullah al-Fatani (Southern Thailand). Although the information concerning most of the scholars is limited, the works and their careers indicated that they were intensively involved in a social and intellectual struggle. Theese scholars had a network. When combined, they were the most important scholars in the archipelago in the 18th century.

The intellectual works of the scholars were generally concerned with the Islamic law or the fiqh. Although these books in part used local languages and adopted local values, Hasby Ash-Shidiqy (in Nourouzzaman, 1996: 236;) argued that these books undeniably had "outside" influence. That is, these works had strong Hijazi, Misri and Iraqi influence as they used the values from the places mentioned. According to him, there are parts of the fiqh based 
upon the Middle Eastern values, then customized with a legal sense of the society of Indonesia. Surely, some parts of such jurisprudence are not fully in accordance with the Indonesian values but remain "imposed" on the basis of taqlid.

The book, Cahaya Suluh, by Muhammad Basiuni Imran (Grand Imam of Sambas) will be reviewed, to see how the process of istinbat law on the legal status of Friday prayer attended by fewer than forty (40) people. At the time, there was a controversy as to the validity of Friday prayer attended by forty people. Basiuni's book was a response to questions dealing with the case. Generally, the Sambas Muslim community follow the opinion of Imam Syafi'i who argued that when there are fewer than forty worshippers, people do not need to perform a Friday prayer. This means that when a place has an insufficient number of worshipers, people must look elsewhere to establish a Friday prayer.

\section{OVERVIEW OF SAMBAS}

Before discussing the position of Muhammad Basiuni Imran as the Imam of Sambas Sultanate, first let us take a glimpse of the history and social conditions of Sambas. With regard to the origin of Sambas, there are two versions. First, J.U. Lontaan in the History, Customary Law and Customs of West Kalimantan said that the name, Sambas, derives from the event of the attack by the British troops into the northern coast of West Kalimantan in 1812. Then spontaneously the three ethnic groups that inhabited the area, --the Malay, Dayak and Chinese-- united to defend the north coastal areas. The attack was crushed by the Chinese, and the battlefield was called Sambas (Sam = three and $\mathrm{Bas}=$ nation).

Second, the opinion expressed by Lutfi Akbar in an Internal Bulletin of Muare Ulakkan, second Edition No. 5 January 1994. In this paper, he said that the name derives from the Quran, i.e. asy-Syam (meaning Sun) and Basmallah (meaning with the name of Allah). This corresponds to Raden Sulaiman as the founder of Sambas who embraced Islam. Both words are associated with the relevant symbol on top of the Palace of the Sultanate of Sambas in the form of the Sun with the words Al Watzikhoebillah (fear of God) underneath it (www. pontianakonline.com).

Sambas was founded around the 1620s by King Tengah, the father of Raden Sulaiman. King Tengah was a son of the descendant of Sultan of Brunei, a younger brother of the monarch of Sukadana Kingdom, Sultan Muhammad Shafiudin. On the 10th Dzulhijjah 1040 AH, circa 1630 AD Raden Sulaiman 
was crowned as the first sultan of Sambas with the title of Sultan Muhammad Shafiuddin (1903: 48). Since then, the Sultanate of Sambas has formally been established. This Sultanate lasted formally over three centuries, and was governed by fifteen (15) sultans, from Raden Sulaiman to the reign of Sultan Ibrahim who was killed by the Japanese in 1943.

Now, based on existing data, Sambas District has an area of 5,554 .70 km2 or 639,570 ha. (4,36\% of the land area of the Province of West Kalimantan). The district is located on the northernmost part of the West coast of the Province of West Kalimantan. The length of its coastal line is $128,5 \mathrm{~km}$, and its border line is approximately $97 \mathrm{~km}$. Geographically, Sambas is situated between 1 ' 23 "North latitude and 103 ' 40" East longitude. The District is bordered by both several regions within Indonesia and that of a neighboring country. The north side of the District is bordered by East Malaysia (Sarawak), the south by Singkawang, the east by Bengkayang, and the west by the Natuna Sea. Sambas administrative regions include 19 sub-districts and 183 villages (in 2008). As of 2007, the population of Sambas District was 538,944 inhabitants consisting of male population of 273,695 and female population 265,294. Meanwhile, the average population density was 76 inhabitants $/ \mathrm{km} 2$.

Most people in Sambas, especially the Malays, are Muslims. Other religions are also embraced such as Christianity, Buddhism and Confucianism. Generally, the Dayaks are either Catholics or Protestants, though basically their religion is Kaharingan (a kind of animism, the belief in ancestral spirits who possess magical powers). Religious grouping has resulted in the Malay being identified as Muslims while the Dayak as Christians.

\section{MUHAMMAD BASIUNI IMRAN AND HIS WORKS}

Muhammad Basiuni Imran was born in Sambas on 25 Zulhijjah or about $1883 \mathrm{AD}$. He was the eldest of four children. His mother died when he was a child and later he was raised by his stepmother, Badriyah. By lineage, the third Imam of the Sambas Sultanate was a descendant of King Gipang, ruler of the Hindu Kingdom located in Sabung, Paloh (Ismail, 1993: 11). In fact, as mentioned in these sources, all previous imams of Sambas Sultanate were descended from King Gipang.

Since the age of 7, Muhammad Basiuni Imran had undergone formal education. Ten years later, when he was a teenager (17 years of age), he went to Mecca to perform pilgrimage and simultaneously to continue his study in the Holy City. He studied there for five years, from 1902 to 1907. In this Holy City, he was trained by scholars, such as Syeikh Ali al-Malik, Umar Sumbawa, 
Usman Serawak, Muhammad Khatib Minangkabau, etc.

After two years of returning home, namely in 1909 Muhammad Basiuni Imran left again for Cairo, Egypt, this time with his younger brother Muhammad Fauzi and two friends, Ahmad and Sood to continue study in Cairo. During his time in Egypt, Muhammad Basiuni Imran studied one year at the Madrasah Dar Al-Da'wah Wa Al-Ershad and three years at Al-Azhar University. His studies actually were not finished yet, but in Sya'ban, 1331AH/1913 AD, Muhammad Basiuni Imran had to return to Sambas since his father was very sick. A month later, in Ramadan 1331AH, his father died. And, some time later in the same year, Muhammad Basiuni Imran was appointed by Sultan Muhammad Ali Syafiuddin as the the 4th Imam of the Sultanate succeeding his father. He was relatively young at the time, i.e. 31 years old.

He was arguably small enough in stature. Muhammad Basiuni Imran's height was only $159 \mathrm{~cm}$, and his weight $48 \mathrm{~kg}$. However, though small in stature, he was highly regarded and respected by the society, especially in Sambas. Expertise in the field of Islamic law made his position very important. In addition to the Sambas Sultanate Imam, he also had a long socio-political career. He served a variety of terms in office. From 1919-1935, he served as the Director of Madrasah al-Sulthaniah Sambas, Adviseur Commisssie Bestuur of Sambas from 1946-1951. Then, from 1966-1975, he became the Sharia Court Chairman of West Kalimantan, a Member of the Indonesian Constituent Assembly. After the 1955 general elections, he became a Representative of Masyumi of West Kalimantan and a member of the Rumbber Commissie in Pontianak. His age was long enough, that is 93 years old. He died in Pontianak, on July 25, 1976 and was buried in his birthplace (Sambas, 1993: 41).

Upon his return to Sambas, he was determined to reform the Islamic teachings. It was inspired by his teacher, Rashid Ridha an innovator in the Islamic world. His teacher is very concerned about the fact that the Muslims were increasingly left behind. In line with the spirit of this innovation, Basiuni Imran wanted to clean up religious practices which were against the Islamic teachings in the midst of the community. According to him, many religious practices had be straightened out immediately before such practices became increasingly entrenched and difficult to distinguish from the teachings which are sourced from the Quran and Hadith. His action was quite successful. He managed to make Sambas a center of religious science so as to become the veranda of Mecca. In addition, Imran also encouraged reform in the Islamic education so that it would not get left by the Western education. He argued that Islamic schools had to adopt Western educational systems in addition to the existing Islamic educational system. 
Muhammad Basiuni Imran produced several works, both in the form of translation and his own books. Generally, these works were written in the Malay language using Jawi (Arabic-Malay) characters. All his works are relatively short. He was like a sprinter who focused on what the local community needed, i.e. to answer the actual problems that developed at that time. His works were written in the style of a fairly simple language in order to be easily understood by the people of Sambas. Among his documented works are as follows:

1. Translation of Darus Attarikh Syariat which is a translation of a summary of the book Durus Tarikh At-Tasyri by Muhammad Ibrahim al-Haitamy. This translation was completed on the 17th of Ramadan 1330 AH/1912 AD by Muhammad Basiuni Imran while he was still in Egypt, a year before he returned home. The manuscript, consisting of approximately 56 pages, contains history of human beings, history of the prophets, history of the development of dakwah and Islamic law. His translation is very systematic with summary and evaluation in each chapter.

2. The book of Cahaya Suluh. Initially, this book outlines of propositions and opinions regarding the validity of Friday prayer. The book was written in order to mediate the debate about the minimum number of people attending a Friday prayer in a mosque. After a careful study on religious references and opinions of ulamas, Basiuni Imran stated in this 19 page book, that it is valid for Friday prayer attended by fewer than forty people. He also quoted earlier opinion of Imam Syafi'i that 4 people would make Friday prayer valid.

3. The book of Tazkir Sabil an-Najah ' $f$ Tarik al-Shalat, a book which discusses the issue of prayer (a sort of fiqh of prayer). The book, consisting of 36 pages, was written in Sambas and printed in Singapore in 1931. The main discussion in this book centers on the sin for those who leave the five-time mandatory prayers except for old age as stipulated by religion. One of his stern fatwas is that a husband or wife who leaves the mandatory prayers is regarded as "infidel" and their marriage is no longer valid. So they do not repent and not renew vow as husband and wife, both will be regarded as committing adultery.

4. The book of al-Janaiz. In accordance with its title, this paper discusses the issues that broadly deal with death and management the corpse. The book consists of 50 pages, and was written during Japanese occupation, i.e. in 1943. 
5. The book of Bidayah al-Tawhid fi Ilm al-Tawhid. The 60-page book contains issues relating to beliefs/aqida. Printed in Singapore in $1344 \mathrm{AH}$.

6. The Nur al-Siraffi al-Isra wa al-Mi'r. This 26-page book contains the story of Isra ' and Miraaj (the Ascension) of Prophet Muhammad which is purely based on the Qur'an and Hadith. It was printed in Singapore in 1938. This book is intended to straighten out the history of the Isra 'and Miraaj, which corresponds to a valid propositions. His references for this book are the books of Hadith such as Sahih Imam Buhkari and its explanation by Al-Allaamah Al-Qastalani, the book of tafsir by Muhammad ibn Jarir, interpretation of the book of Sahih Muslim by Imam Al-Nawawi, the book of Zad al-Ma’ad by Imam Ibn Al-Qayyim, and Nur al-Yaqin by Muhammad al-Khudhari Al-Mishri.

7. The book of Khasanah al Sirah al Muhammadiah. The nature of Islamic Proselytization, printed inSingapore in 1351 AH/1932 AD. This book is a translation from the Arabic version by Muhammad Rashid Ridha. This 101-page book contains the history of the life, da'wah and struggle of Prophet Muhammad (pbuh).

\section{THE OPINION OF SOME SCHOOLS OF THOUGHT ON THE ISSUE}

There is a difference of opinion in the law with regard to the minimum number of Friday prayer worshipers. Imam Abu Hanifah, for example, argued that the ruling for Friday prayer could be done by a minimum of three people, even though they are on a journey or sick. The number of people, as many as 40 , does not include in the terms of valid Friday prayer. However, the more the number, the better the prayer is. His opinion is based on the generality of Hadith of Prophet that says: "the prayer of a man followed with another man is better than praying alone. The prayer of a man followed by two men is better than a prayer followed by a man. The greater number, the more it is favored by Allah Azza Wa Jalla “. (Narrated by Abu Dawud, No. 554 and Nasa'i No. 843 , verified by al-Bani). However, if there are only 3 people who gather at a mosque, it is legitimate for them to perform Friday prayer at the venue. It is based on the Prophet's Hadith that reads: "Narrated by Abu Said Al Khudri: "the Messenger of Allah, peace be upon him, said: "if they consist of three people, then let one of them to be the imam. The one who is most entitled to be the imam is he who has the most pleasant reading of the Quran ". (Muslim, No. 1077).

The opinion of Imam Abu Hanifah is viewed as the most valid opinion of a wide range of opinions. Friday prayer does not have to be performed by 40 people as required by one of the scholars of Islamic law, namely Syafi'i. This opinion was selected by Ibn Taymiyah in the book of al-Ikhtiyarat al 
Ilmiyyah: 119-120, and also of the opinion of Imam Ahmad Ibn Hanbal (see Sharh Ushulul al-Ihkam Ahkam, Abdurrahman bin al-Qasim 1: 442-444), and likewise the opinion of Sheikh Abdul Aziz bin Bazz (Shalatul Mukmin, Syeikh Saad al-Qahtani 2: 802).

In contrast to Imam Abu Hanifah, Imam Malik argued that the minimum worshipers for Friday prayer should be 12. This opinion is based on the Hadith narrated from Jabir that once the Prophet was preaching on a Friday, the sermon was underway and suddenly some traders from Sham arrived. The arrival of these traders had caused the Friday worshipers to turn away from the Prophet and only 12 people were left. This even was the cause of the revelation for Quranic verses) surah al-Jumu'ah verse 11 that reads "But when they saw a transaction or a diversion, they rushed to it and left you standing (preach)". Judging from this, Imam Malik believed that Friday prayer can be exercised with 12 people.

Meanwhile, Imam Syafi'i, as expressed above, argued that Friday prayers can only be done with a total of 40 people or more. In addition to the number, this school also made additional terms for the imam. One who acts as the imam of the prayer should be local, having reached puberty, sensible, independent and male. Although a traveler s allowed, the number performing Friday prayer should be forty people or more. The evidence used is the Hadith narrated by Al-Baihaqi from Ibn Mas'ud as saying the Prophet performed Friday prayer in Medina and the number of people was forty. (Fiqhul Islami wa Adillatuhu. Volume II: 1295-1297).

In addition to the above opinion, Hasbi ash-Shiddiqy - one of the Indonesian fuqahas, who served as Dean of the Faculty of Sharia of UIN Yogyakarta--has a slightly different opinion. Hasbi ash-Shidiqy argued (1997: 398) that Friday prayers do not require any number of worshipers. The difference between obligatory prayers and Friday prayer is simply the sermon. Therefore, according to him, it is compulsory upon every person to establish Friday prayer even though there are only a few people. As for the Dhuhr prayer after Friday prayer because there are fewer than 40 people, is not justified. This opinion is based on the opinion of al-Asybily in his Ahkam as saying that "there is no valid Hadith which determines the number of Friday prayer worshippers." It is also, based on the opinion expressed by Imam as-Suyuthy in Nurul Lamiah (Ash-Shidiqy; 1997: 390). If observed further, the opinion of this Hasbi ashShiddiqy is closer or similar to Hanafi's opinion which also does not make restrictions against the number of worshipers on Fridays.

Regarding the prayer of Dhuhr as a complement to the shortage of the number of worshipers to pray Friday, as briefly described above, it is still debatable. 
Muhammad Shakir (2006: 231)-former Rector of UIN Jakarta---said that Friday prayer is the replacement for Dhuhr prayer. Therefore, there is no obligation or recommendation to those who have performed Friday prayer to establish Dhuhr prayer, although the number of its worshippers did not reach 40. According to him, two sermons in Friday prayer is the replacement of the two rak'ahs of Dhuhr prayer. In fact, for those who miss Friday prayer are not required to pray Dhuhr. But, if a person only completed one rak'ah, then he must improve his prayer into four rak'ahs, although his intention when standing was to establish Friday prayer.

\section{BASIUNI IMRAN'S OPINION ON FRIDAY PRAYER FEWER THAN 40 PEOPLE}

The book of Cahaya Suluh is a book which elaborates on propositions and opinions regarding the question of Muhammad Basiuni Imran on conditions valid for Friday prayer. This book was written in order to mediate the debate about the minimum number of worshipers praying on a Fridaywhen there are fewer than forty people. The controversy arises because there is a difference of opinion among the scholars concerning the determination of the number of Friday worshipers. Hanafi is in contrast to Maliki, while Syafi'i also determines a different number of worshippers.

Muhammad Basiuni Imran began to express his opinion when people asked him about the law for Friday prayer attended by fewer than forty people and about the obligation for Dhuhr prayer (Basiuni Imran; the book Cahaya Suluh, 1339: 1). To avoid conflict, a legal fatwa from Imam of Sambas was required. With a fatwa on this issue, the Sambas community was expected to know the legal position. The core problem is the existence different opinion from that of Syafi'I regarding Friday prayer. Meanwhile, as generally understood, Indonesia's Muslims adhere to acknowledge Imam Shafi'i's who argued that Friday prayer can be implemented when it meets certain conditions, one of which is the number of worshipers should be forty people.

In Cahaya Suluh, it is mentioned that the valid terms for Friday prayer (Basiuni Imran; 1339: 3) are as follows:

1. the place of residence (country or village) that is recognized by people who pray on Fridays.

2. the number in the Friday prayer should consist of 40 male worshipers who are Muslims, have reached puberty, are independent and remain in the country or village where Friday prayer is established with provisions that they are not traveling elsewhere at the time except when they have to (for trade or 
other purposes).

3. it should be done at Dhuhr time.

In other parts, Basiuni Imran made important note that Friday prayer is valid although attended by fewer than 40 worshipers. This view is based on Imam Al-Syafi'i Qodim Qawl. In the Hadith of Shahih Muslim (al-Jumu'ah bab fi Qaulihi Taâla Chapter III: 351) it is suggested that the Prophet performed Friday prayer with 12 people. In this Hadith, it does not require 40 people to establish Friday prayer, just 12 people. So, when a village does not have 40 people and they cannot go to a prayer attended by 40 people, then they must establish Friday prayer in their place (village) (Basiuni Imran; 1339: 2)

Muhammad Basiuni Imran's view is a little bit controversial if linked to his position as an advocate of Imam Syafi'i. But, it seems, for the consideration of socio-culture of Sambas society, he then preferred the school of Imam Syafi'i. This is because the Qawl Qadim was viewed to be in line with the conditions of society at this time. Qawl Qadim is the view of Imam Al-Syafi'i which is regarded as rational, while Qawl Jadid is the opinion based on the Hadith (textual).

To explain this issue, the view of Muhammad Basiuni Imran is quite comprehensive since he not only used but aqli propositions but naqli proposition as well. Based on his naqli opinion on the Hadith which was narrated by Muslim as saying that the Prophet once performed Friday prayer with 12 people. As mentioned in the Syarh Muslim from Jabir bin Abdullah that the Prophet was reading a sermon on Friday, and when the sermon was being conducted, all of a sudden trade groups from the Sham arrived there. The Friday worshippers rushed to see the traders and only 12 men were attending the prayer. The event was recorded in the Qur'an surah Jumu'ah verse 11 . As argued by Imam Nawawi this verse is the evidence presented by Imam Malik about Friday prayer being valid with only 12 worshipers. With regard to this evidence, Muhammad Basiuni Imran had the opinion that the minimum number of people for Friday prayer can be fewer than 40. Thus, according to him the Qawl Jadid for the minimum number of 40 people in Friday prayer is not strong.

Meanwhile, his aqli opinion was based on the consideration of socio-culture state of the Sambas society at the time. The villages in the region of Sambas had population of not less than one hundred people, but sometimes those who came to the mosque for Friday prayer was fewer than 40 people. If one only considers the opinion of Imam Syafi'i (Qawl Jadid) which requires that the exercise of Friday prayer with at least 40 worshipers, it would bring 
serious implications. The strict enforcement of this requirement would cause or trigger problems in various villages and hamlets because people in many villages and hamlets would not establish Friday prayer. Therefore, it is highly rational when Muhammad Basiuni Imaran as the Grand Imam of Sambas issued a fatwa Friday prayer is valid even though there are fewer than 40 people in attendance. With the issuance of this fatwa, the controversy regarding the minimum number of worshipers to pray on Fridays could be resolved. From the purposive viewpoint, the fatwa was very smart because it took local conditions into consideration.

The next question which must be answered is the legal position of the Dhuhr prayer. As commonly practiced, Friday prayer is attended by fewer than 40 worshipers, it then must be complemented with Dhuhr prayer. To address this issue, Muhammad Basiuni Imran mentioned that there is no provision of law requiring the implementation of Dhuhr prayer. According to him, the opinion that requires implementation of the Mu'adah Dhuhr prayer is the view of Imam Syafi'i. In fact, its legal status is actually sunnah. That is, there is no argument for performing Mu'adah prayer after Friday prayer, although the latter is performed by only several people. (Imran Basiuni; 1339: 12). If analyzed, his answer to the issue is interesting and controversial. From the viewpoint as the advocate of Syafi'i, his opinion is contrary to his school of thought. That is, even though he was an adherent of the school of Syafi'I, he did not fully "comply" to it. However, although he had a different opinion in this case, as the Grand Imam of Sambas he took a wise stand. Even though he never perfeorm Dhuhr Mu'adah prayer, he never banned this practice. (Imran Basiuni; 1339: 14).

The reference he used was the Prophet's Hadith narrated by Bukhari and Muslim, which reads: "pray and be cautious with the prayer of the Messenger who performs two rak'ahs of Friday prayer and two rak'ahs of sunnah prayer after Friday prayer." This Hadith confirms that the Prophet performed two rak'ahs of Friday prayer and two rakiahs of sunnah prayer. The Prophet never performed Dhuhr prayer after Friday prayer. Indeed there is a Hadith which suggests four rak'ahs of prayer after Friday prayer, reads: "idza shalli ahadukumu al-jumat, fa al-yushalli ba'daha arba'an" (when one has completed Friday prayer, he should perform four rakahs of prayer). However, he (Basiuni Imran) said that this Hadith is not related to Mu'adah Dhuhr prayer, rather it is just an affirmation of the importance of the sunnah prayer after Friday prayer. (Imran Basiuni; 1339: 15). Thus, it can be concluded that the pattern of thought of Muhammad Basiuni Imran is flexible and moderate enough. In addition to referring to the text, he also considered the social and cultural conditions in istinbat (the 
process of deriving certain rules or meanings from a text).

\section{CONCLUSION}

The reading of the intellectual heritage such as the book of Cahaya Suluh, will at least give us an idea that in a process of setting certain rules or istinbat, the re need for flexibility. As can be observed from the whole argument built in this book, the process is completely flexible, not merely following one school of thought. As indicated in this paper, especially in the discussion of his thought, Muhammad Basiuni Imran used various references for his propositions. Although he was an advocate of the school of Syafi'i, he was still open to the other schools of thought. As a matter of fact, in the case of Friday prayer, his position was different from the school of thought he supported. He took that position because he considered the socio cultural conditions of Sambas at the time.

Intellectual spirit shown by the Grand Imam of Sambas should continue to be emulated and expanded. It is a way to avoid the 'blind' taqlid against a certain school of thought, as such attitude can narrow human intelligence and reasoning which will eventually lead to collision with local reality that sometimes contains values that do not contradict with religion. The ulamas should serve as 'soothers' and be able to accept other people's opinions so as to avoid tension in the lower levels of society which in the end will only hurt the Muslims themselves.

The approach to the interpretation of law should look at its socio-cultural and historical background as this will keep the law strong and sustainable. In this way, Islam will be easily accepted without having to impose foreign culture on local people. A religion spread wisely will not be incompatible with local culture, but in fact both will be able to mutually enrich and co-exist.

\section{BIBLIOGRAPHY}

Abudinata (2002): "Metodologi Studi Islam", Rajawali Press, Jakarta. Azyumardi Azra (1995): "Jaringan Ulama Timur Tengah dan Kepulauan Nusantara Abad XVII dan XVIII", Mizan, Bandung

Basiuni Imran (1339); "Kitab Cahaya Suluh", Singapura.

Erwin Mahrus dkk (2003); "Shykh Khatib Sambas, Sufi dan Ulama Besar dikenal Dunia (1803-1875), UNTAN Press, Pontianak

Ibn Rusyd (tt): "Bidâyat al-Mujtahid", Beirut; Dâr al-Fikr 
Imam Muslim dalam Shahîhnya kitab al-Jumu'ah bab fi Qaulihi Tẩla Jilid III

Ismail (1993); "Mengenal Muhammad Basiuni Imran, Maharaja Kerajaan Sambas", UNTAN, Pontianak

Komaruddin Hidayat \& Ahmad Gaus AF (2006); "Menjadi Indonesia, 13 Abad Eksistensi Islam di Bumi Nusantara", MIZAN, Jakarta

M. Quraish Shihab (2006); "Tafsir Al-Mishbah", Volume 14, Lentera Hati, Jakarta

Muhsin Z (2007); Artikel "Teori Masuknya Islam ke Nusantara", Universitas Padjajaran, 2007, Jatinangor

Mu'jizah (2005); "Martabat Tujuh, Edisi Teks dan Pemaknaan Tanda Serta Simbol", Jambatan-Yayasan Naskah Nusantara dan The Ford Foundation, Jakarata

Nourouzzaman Shiddiq (1996); "Jeram-jeram Peradaban Muslim”, Pustaka Pelajar, Yogyakarta

Pabali Musa (2003); "Sejarah Kesultanan Sambas Kalbar", STAIN Pontianak Press dan The Ford Foundation, Pontianak

Wahbah Zuhaily (1996); "al-Fiqh al-Islami wa adillatuh", Jilid II, Beirut; Dâr al-Fikr 
